
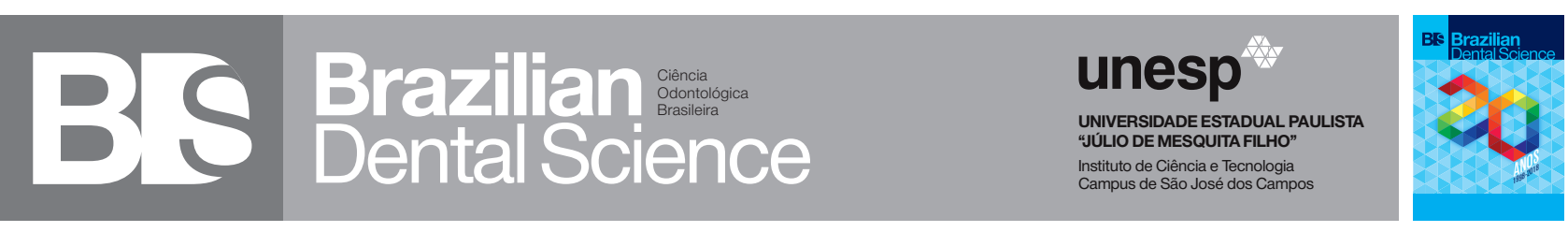

\title{
Bond strength of resin cements to novel materials to intracanal posts applications
}

Resistência de união de cimentos resinosos a novos materiais para pinos intrarradiculares

Lígia Gabrielle Sanches MARIOTTO ${ }^{1}$, Carla Larissa VIDAL ${ }^{1}$, Denise Tornavoi de CASTRO ${ }^{2}$, Alma Blásida Concepcion Elizaur Benitez CATIRSE ${ }^{1}$, Rossana Pereira de ALMEIDA ${ }^{1}$, Andréa Cândido dos REIS ${ }^{1}$

1 - Department of Dental Materials and Prosthesis - School of Dentistry of Ribeirão Preto - University of São Paulo - Ribeirão Preto - SP - Brazil.

2 - Department of Biomaterials - School of Dentistry of Uberaba - Uberaba - MG - Brazil.

\section{ABSTRACT}

Objective: Evaluate the bond strength of resin cements to new materials for application in intraradicular posts. Material and Methods: Five materials were evaluated: fiberglass, PET, polyethylene, polyacetal and PTFE. Two commercial resin cements (Rely X U200 and Rely X Arc) were applied on the test specimens of the materials $(9 \times 3 \mathrm{~mm})$ and the bonding was evaluated through the shear bond strength test, where the chisel operated with a load of $1 \mathrm{kN}$ and a velocity of $0.5 \mathrm{~mm} / \mathrm{min}$ at the cement/material interface. The data were analyzed by the Shapiro-Wilk test, followed by the two-way analysis of variance, performed with the Bonferroni post-test $(\alpha=0.05)$. Results: The glass fiber was statistically different from all evaluated materials $(\mathrm{p}<0.05)$. There was no statistically significant difference between the other materials ( $p>0.05)$. Comparing the two cements, a statistical difference was found between Rely X U200 and Arc only for the glass fiber $(\mathrm{p}=0)$. Conclusion: PET, polyethylene, polyacetal and PTFE exhibited reduced bond strength compared to the glass fiber.

\section{KEYWORDS}

Resin cement; PET polymer; Polytetrafluoroethylene.

\section{RESUMO}

Objetivo: Avaliar a resistência de união de cimentos resinosos a novos materiais para aplicação em pinos intrarradiculares. Material e método: Foram avaliados cinco materiais: fibra de vidro, PET, polietileno, poliacetal e PTFE. Dois cimentos resinosos comerciais (Rely X U200 e Rely X Arc) foram aplicados sobre os corpos de prova dos materias $(9 \times 3 \mathrm{~mm})$ e a resistência de união foi avaliada através do teste de cisalhamento, onde o cinzel atuou com carga de $1 \mathrm{kN}$ e velocidade de $0,5 \mathrm{~mm} / \mathrm{min}$ na interface cimento/material. Verificada a normalidade dos dados através do teste Shapiro-Wilk, foi realizada a análise de variância de dois fatores com pós-teste de Bonferroni $(\alpha=0,05)$. Resultados: a fibra de vidro foi diferente estatisticamtente de todos os materiais avaliados $(\mathrm{p}<0,05)$. Os demais materiais não apresentaram diferença estatiscamente significante entre si ( $p>0,05)$. Comparando-se os dois cimentos, foi encontrada diferença estatística entre o Rely X U200 e Arc apenas para a fibra de vidro $(\mathrm{p}=0)$. Conclusão: $\mathrm{PET}$, polietileno, poliacetal e PTFE apresentaram resistência de união reduzida comparando-se à fibra de vidro.

\section{PALAVRAS-CHAVE}

Cimentos de resina; Polietilenotereftalatos; Politetrafluoretileno. 


\section{INTRODUCTION}

$\mathrm{T}$ he use of intraradicular posts is the main retention method used in coronal restorative material for endodontically treated teeth with pronounced coronal destruction. $[1,2]$ Traditionally, metal posts were used for intraradicular retention and had high survival rates after 10 years. [3] Notwithstanding, due to the high modulus of elasticity of the metal compared to dentin, which increases the risk of root fracture and catastrophic failure, [4] fiberglass posts were introduced as an alternative. [1]

Prefabricated intraradicular fiber posts have been suggested as a promising restorative material due to their favorable aesthetics, biocompatibility, reduced treatment time and modulus of elasticity, which is similar to dentin. $[5,6,7]$ Due to their modulus of elasticity, these posts promote better stress distribution along the root axis. [8] Consequently, fiberglass and carbon posts are widely used in oral rehabilitation. [9, 10, 11] However, a failure rate of up to $7 \%$ is still reported for treatments using these intracanal retainers [12] and no differences have been found in the incidence of root fractures between the use of these retainers and metal posts. [7] Thus, new materials that reduce these problems are highly desirable for this application.

Poly (ethylene terephthalate), known by the acronym PET and commercially known as DACRON $\AA$, available since the 1970 s, is widely applied in the medical field, representing the material most used for vascular substitutes in cardiovascular surgery $[13,14]$, due to its good postoperative performance and biocompatibility. [15] PET is a semi-crystalline transparent thermoplastic polymer material, which has become popular in dentistry due to its aesthetics and ductility. It is used for making orthodontic aligners, vacuum formed retainers, night protectors, temporomandibular joint splints, bleaching plates, etc. [16-18]

Polyethylene, widely applied in Dentistry and commonly used in prosthetic components and as reinforcing fibers, is the most durable reinforcing fiber available. This material consists of aligned polymer chains with low density and good impact resistance. Because of its white color, it can be used in aesthetic dental applications. $[19,20]$

Polyacetal is a semi-crystalline thermoplastic material, which is applied in several areas such as in the automobile, medical, dental, electronic, electrical areas, and other areas. In dentistry, due to its mechanical properties, biocompatibility, and favorable esthetics, it is applied in removable partial dentures, making it a good alternative for a removable partial prosthesis with chromiumcobalt alloys. [21]

Polytetrafluoroethylene

(PTFE), commonly known by the trade name Teflon, is a polymeric material that has common uses outside of dentistry. Its applications include integration in kitchen appliances and building materials, as well as computer circuits and components. [22] In dentistry, it has been used for tissue-guided regeneration, coating instruments to improve the handling properties and matrices. [22-24]

Currently, resin cements are the most used materials to attach posts to the dentin of the root canal. However, in vivo and in vitro studies have shown that loss of retention is the predominant mode of failure in fiber posts after restorations $[25,26]$.

The evolution and innovation of dental materials is recommended to provide technical facilitation and/or to improve chemical, physical and mechanical properties, bringing them closer to the values presented by the dental structures. In the case of the intraradicular posts, specifically, modulus of elasticity, to promote homogeneity in the dissipation of forces between the structures and prevent fractures and localized stress overload, suggesting long-term rehabilitation durability.

With this objective, the present study evaluated the bond strength of five materials (PET, polyethylene, polyacetal, PTFE and 
fiberglass) in resin cements commonly used in dental practice, as a future recommended application in intraradicular posts using the shear bond strength test.

\section{MATERIALS AND METHODS}

Five materials were used: PET, fiberglass, polyacetal, polyethylene, and PTFE and two commercial resin cements: RelyX U200 and RelyX Arc (3M ESPE, St. Paul, MN, USA).

Test specimens $(n=5)$ from each material were prepared in the dimensions of $9 \times 3 \mathrm{~mm}$. The specimens were included in PVC rings with auto-polymerized acrylic resin (Clássico ( , Art. Clássico, São Paulo, SP) so that one of the faces was exposed and centered in the ring (Figure 1).

The cements were provided and handled according to the manufacturer's instructions. A
$2 \mathrm{~mm} \times 2 \mathrm{~mm}$ plastic matrix was insulated with Vaseline, positioned in the center of the exposed face and filled with cement with a metal spatula in small portions, which was photopolymerized according to the manufacturer's instruction for 20 seconds. Subsequently, the plastic matrix was removed (Figure 2).

For the evaluation of the bond strength between the materials and the cements, the specimens were submitted to the shear strength test, performed in a universal testing machine (EMIC DL 2000, São José dos Pinhais, Paraná, Brazil), with a $1 \mathrm{kN}$ load cell and velocity of $0.5 \mathrm{~mm} / \mathrm{min}$, where the chisel was positioned at the material/cement interface. The shear strength values were recorded in MPa.

After verifying the data through the Shapiro-Wilk test, the two-way analysis of variance with Bonferroni post-test was performed $(\alpha=0.05)$.

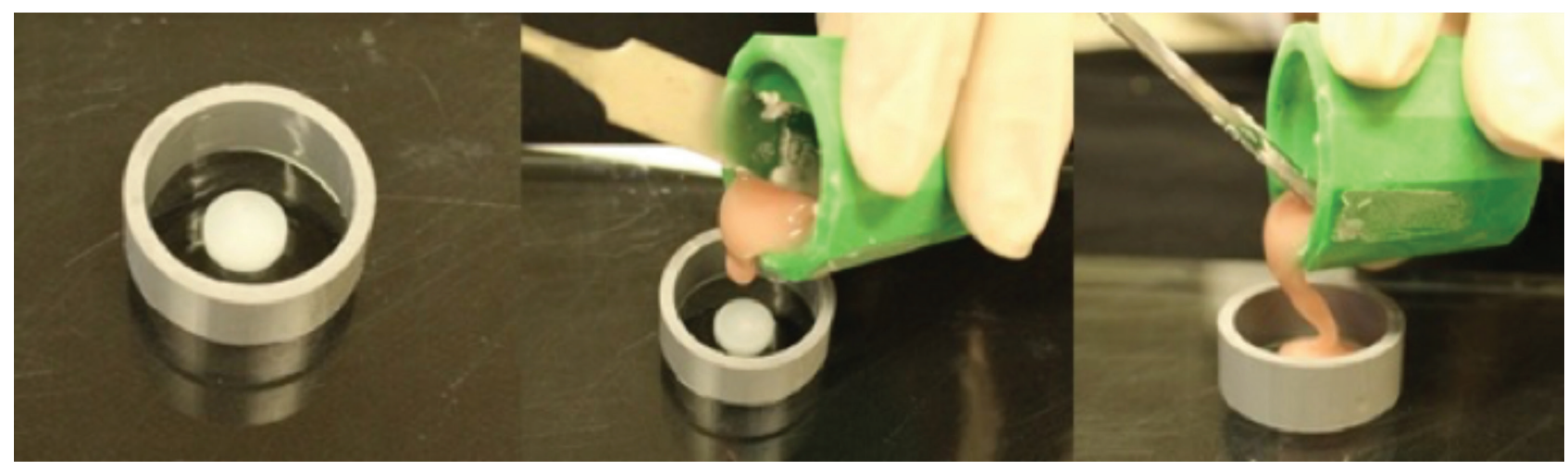

Figure 1- Inclusion of test specimens to PVC matrix with auto-polymerized acrylic resin.

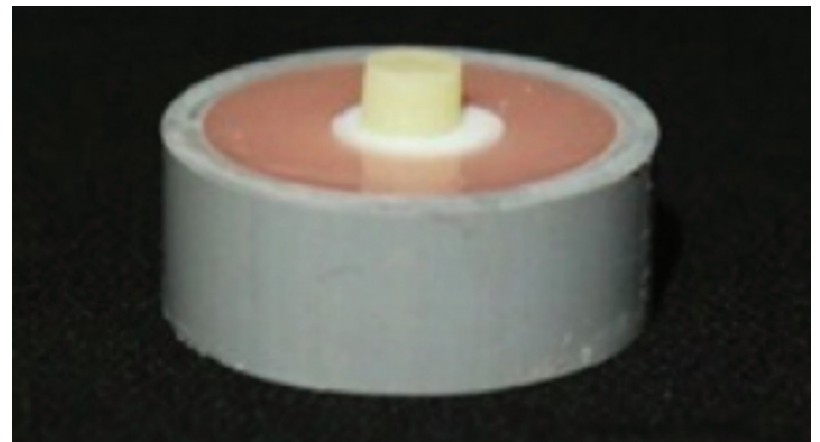

Figure 2 - The test specimen included in acrylic resin with photopolymerized cement.

\section{RESULTS}

The values of the bond strength of the different materials evaluate are expose in table 1. The intermaterial evaluation of the RelyX U200 cement showed that only the fiberglass material was statistically different from all the other materials evaluated ( $p<0.05)$. In the RelyX Arc cement evaluation, the materials did not exhibit the statistically significant difference between them $(\mathrm{p}>0.05)$. 
In the evaluation between the cements, the fiberglass exhibited the statistical difference between the Rely X U200 and Arc (p = 0).

Table 3 - General description of the sample and comparison of the right $(\mathrm{RM})$ and left (LM) measurements

\begin{tabular}{|c|c|c|}
\hline \multirow{2}{*}{ Material } & \multicolumn{2}{|c|}{ Cement } \\
\hline & RelyX U200 & RelyXArc \\
\hline PET & $1.46(0.66)^{\mathrm{Aa}}$ & $1.38(0.97)^{\mathrm{Aa}}$ \\
\hline Fiberglass & $7.41(3.23)^{\mathrm{Ba}}$ & $2.47(0.68)^{\mathrm{Ab}}$ \\
\hline Polyacetal & $2.05(0.71)^{\mathrm{Aa}}$ & $0.95(0.72) \mathrm{Aa}$ \\
\hline Polyethylene & $1.22(0.39)^{\mathrm{Aa}}$ & $1.25(0.61)^{\mathrm{Aa}}$ \\
\hline PTFE & $0.73(0.51)^{\mathrm{Aa}}$ & $0.46(0.25)^{\mathrm{Aa}}$ \\
\hline
\end{tabular}

${ }^{A B}$ Equal capital letters indicate statistical similarities in the column.

${ }^{a b}$ Equal lowercase letters indicate statistical similarities in the line

\section{DISCUSSION}

Fiberglass posts have been extensively used in oral rehabilitation, bringing improved resistance and dissipation of intracanal forces compared to metallic posts. Problems such as restoration retentions in these materials were overcome with the use of resin cements. [27] The clinical success of this alternative treatment has been mainly attributed to the modulus of elasticity of fiberglass posts, which is closer to the dentin structure module than to metal pins [28].

The modulus of elasticity represents the flexibility of the material, where high values indicate a hard material and low values, a flexible material. [29] Diameter, type of fiber and material can influence the property of prefabricated fiber posts. [30] Thus, the modulus of elasticity is related to the stress transmitted to the root, which is one of the most important factors in the fracture mechanism. [31]

Restored teeth with prefabricated metal posts or molten metal cores have high fracture strength values [32]. However, their failure mode causes irreversible fractures and dental loss. This can be explained by the modulus of elasticity of these posts, which have higher modulus of elasticity than the fiber posts and generate high-stress concentration in the remaining root structure. [33] Although the fiberglass has a modulus of elasticity closer to the root dentin than to the metal one, $[4,8]$ which would reduce root fracture cases when comparing these two materials, there is no difference in the incidence of this problem. [7]

Modulus of elasticity discrepancy is a source of stress concentrations, notwithstanding the smaller modulus of elasticity of the fiberglass, and the pins of this material do not contribute to better stress distribution in the tooth root, increasing the risk of root fracture. [34]

In this study, the four new materials evaluated, PET, PTFE, polyacetal, and polyethylene, exhibited lower bond strength values than the fiberglass group for the RelyX U200 cement, commonly used as intraradicular retainers in clinical procedures. For the Relyx ARC cement, no statistics differences were found among the groups evaluated. [1,5-7,911,27] However, clinically speaking, a reduced incidence of catastrophic failures, which does not allow replacing the restoration, may be more important than the survival rate of the restoration. [7]

The human dentin exhibits a modulus of elasticity of $19.3 \mathrm{GPa}$ [35], while for fiberglass it is $41.87 \mathrm{GPa}$ [36]. For the new materials evaluated, the elastic modulus values for PTFE are $1.46 \mathrm{GPa}$ [37], $1.16 \mathrm{GPa}$ for polyacetal [38], $0.74 \mathrm{Gpa}$ for polyethylene [39] and 2.7 Gpa for PET. [40] Notwithstanding the low values, which can be altered considering that the final product in the form of pins has threads and roughness, which increase the bonding surface of the cement, these values are closer to the ones found for the dentin than for the fiberglass.

Thus, despite the lower bond strength values, the greater proximity of the modulus of elasticity values of the new materials to those found for human dentin could bring more favorable results to restorations that require intraradicular retainers, since there would be a decrease in cases of root fracture. 


\section{CONCLUSION}

The evaluated materials, PET, PTFE, polyethylene, and polyacetal, showed reduced bond strength when compared to fiberglass. However, their modulus of elasticity is closer to that of the dentin.

\section{REFERENCES}

1. Ferrari M, Vichi A, Fadda GM, Cagidiaco MC, Tay FR, Breschi L, etal. A randomized controlled trial of endodontically treated and restored premolars. J DentRes. 2012 Jul;:91(7 Suppl):72S-78S.

2. Sarkis-Onofre R, Jacinto RC, Boscato N, Cenci MS, Pereira-Cenci T.Castmetal vs. glass fibre posts: a randomized controlled trial with up to 3 years of follow up. J Dent. 2014 May;42(5):582-7. doi:10.1016/j.jdent.2014.02.003. Epub 2014 Feb12.

3. Gómez-Polo M, LlidóB, Rivero A, Del Río J,Celemín A. A 10-year retrospective study of the survival rate of teeth restored with metal prefabricated posts versus cast metal posts and cores. J Dent. 2010 Nov;38(11):916-20. doi:101016/j. jdent.2010.08.006. Epub 2010 Aug 14.

4. ZaroneF, Sorrentino R, Apicella D, Valentino B, Ferrari M, Aversa R, etal. Evaluation of the biomechanical behavior of maxillary central incisors restored by means of endocrowns compared to a natural tooth: a 3D static linear finite elements analysis. Dent Mater. 2006 Nov;22(11):1035-44. Epub2006 Jan 10.

5. Cheung W. A review of the management of endodontically treated teeth: post, core and the final restoration. J Am Dent Assoc. 2005 May;136(5):611-9.

6. Bateman G, Ricketts DNJ, Saunders WP.Fibre-based post systems: a review. Br Dent J. 2003 Jul 12;195(1):43-8; discussion 37.

7. Figueiredo FED, Martins-Filho PRS, Faria-e-Silva AL. Do metal postretained restorations result in more root fractures than fiber post-retained restorations? A systematic review and meta-analysis. JEndod. 2015 Mar:41(3):309-16. doi:10.1016/j.joen.2014.10.006. Epub 2014 Nov 11.

8. Santos-Filho PC, Veríssimo C, Soares PV, Saltarelo RC, Soares CJ, Marcondes Martins LR. Influence of ferrule, post system, and length on biomechanical behavior of endodontically treated anterior teeth. J Endod. 2014 Jan;40(1):11923. doi:10.1016/j.joen.2013.09.034. Epub20130ct27.

9. Chuang SF, Yaman P, Herrero A, Dennison JB, Chang $\mathrm{CH}$. Influence of post material and length on endodontically treated incisors: an in vitro and finite element study. JProsthet Dent. 2010 Dec;104(6):379-88. doi:10.1016/S00223913(10)60171-0.

10. Ambica K, Mahendran K, Talwar S, Verma M, Padmini G, Periasamy R. Comparative evaluation of fracture resistance under static and fatigue loading of endodontically treated teeth restored with carbon fiber posts, glass fiber posts, and an experimental dentin post system: an in vitro study. J Endod. 2013 Jan;39(1):96-100. doi: 10.1016/j.joen.2012.07.003. Epub2012Sep 11.

11. Goracci, C, Ferrari M. Current perspectives on post systems: a literature review. Aust Dent J.2011 Jun;56 Suppl 1:77-83. doi: 10.1111/.1834-7819.2010.01298.x.

12. Bitter K, Noetzel J,Stamm 0, Vaudt J, Meyer-Lueckel H, Neumann K, etal. Randomized clinical trial comparing the effects of post placement on failure rate of postendodontic restorations: preliminary results of a mean period of 32 months. JEndod. 2009 Nov;35(11):1477-82. doi: 10.1016/j.joen.2009.07.026. Epub2009Sep 18.

13. Hussain A, Curry B, Cahalan L, Minkin S, Gartner M, Cahalan P.Development and in vitro evaluation of infection resistant materials: A novel surface modification process for silicone and Dacron. J Biomater Appl. 2016 Feb;30(7):1103-13. doi: 10.1177/0885328215607378. Epub 2015 Nov 24.

14. Spadaccio C,Nappi F,Al-Attar N, Sutherland FW, Acar C, Nenna A, etal. Old myths, new concerns: the long-term effects of ascending aorta replacement with Dacron grafts. Not all that glitters is gold. J Cardiovasc TransI Res. 2016 Aug;9(4):334-42. doi: 101007/s12265-016-9699-8. Epub2016 May 31.

15. Bustos CA, García-Herrera CM, Celentano DJ. Mechanical characterisation of Dacron graft: Experiments and numerical simulation. J Biomech. 2016 Jan 4;49(1):13-18. doi:10.1016/j.jbiomech.2015.11.014. Epub 2015 Nov 28.

16. Zhang $N$, Bai Y,Ding X, Zhang Y.Preparation and characterization of thermoplastic materials for invisible orthodontics. Dent Mater J. 2011;30(6):954-9. doi: 10.4012/dmj.2011-120. Epub 2011 Nov 25.

17. Goldberg AJ,Burstone CJ. The use of continuous fiber reinforcement in dentistry.Dent Mater. 1992 May;8(3):197-202

18. Fang J, Wang C,LiY,Zhao Z, Mei L. Comparison of bacterial adhesion to dental materials of polyethylene terephthalate (PET) and polymethyl methacrylate (PMMA) using atomic force microscopy and scanning electron microscopy. Scanning. 2016 Nov;38(6):665-670. doi:10.1002/sca.21314. Epub 2016 Mar 15.

19. Edwards KL. An overview of the technology of fibre-reinforced plastics for design purposes. Mater Design. 1998;19(1-2):1-10.

20. Mangoush E, SälynojaE,Prinssi R. Comparative evaluation between glass and polyethylene fiber reinforced composites: A review of the current literature.J Clin Exp Dent. 2017 Dec 1;9(12):e1408-e1417.doi:10.4317/jced.54205. eCollection 2017 Dec.

21. Birley AW. Plastics materials: properties and applications. Berlim:Springer Science \& Business Media; 2012

22. Sattar MM, Patel M, Alani A. Clinical applications of polytetrafluoroethylene (PTFE) tape in restorative dentistry. Br Dent J. 2017 Feb 10;222(3):151-158. doi: 10.1038/s.bdj.2017.110.

23. Bottino MC, Thomas V, Schmidt G, Vohra YK, Chu TM, Kowolik MJ, etal. Recent advances in the development of GTR/GBR membranes for periodontal regeneration-a materials perspective. Dent Mater. 2012 Jul;28(7):703-21. doi: 10.1016/j.dental.2012.04.022. Epub 2012 May 14.

24. Stean, H. PTFE tape: a versatile material in restorative dentistry. Dent Update. 1993 May;20(4):146-8.

25. Zhou L, Wang Q. Comparison of fracture resistance between cast posts and fiber posts: a meta-analysis of literature. JEndod. 2013 Jan;39(1):11-5. doi: 10.1016/j.joen.2012.09.026. Epub 20120ct24.

26. Cecchin D, de Almeida JF,Gomes BP,Zaia AA, Ferraz CC. Effect of chlorhexidine and ethanol on the durability of the adhesion of the fiber post relined with resin composite to the root canal. J Endod. 2011May;37(5):678-83. doi:10.1016/j. joen.2011.01.007.Epub 2011Mar5.

27. Hayashi M, Sugeta A, Takahashi Y,Imazato S, Ebisu S. Static and fatigue fracture resistances of pulpless teeth restored with post-cores. Dent Mater. 2008 Sep;24(9):1178-86. doi:10.1016/j.dental.2008.01.009. Epub2008 Mar 28.

28. Kinney JH, Marshall SJ, Marshall GW. The mechanical properties of human dentin: a critical review and re-evaluation of the dental literature. CritRev Oral Biol Med. 2003;14(1):13-29.

29. Stewardson DA, Shortall AC, Marquis PM., et al. The flexural properties of endodontic postmaterials. Dent Mater.2010 Aug;26(8):730-6. doi:10.1016/j. dental.2010.03.017. Epub 2010 Apr 21.

30. Asmussen, E, Peutzfeldt, A, Heitmann, T. Stiffness, elastic limit, and strength of newer types of endodontic posts. J Dent. 1999 May;27(4):275-8. 
31. Coelho CS, Biffi JC, Silva GR, Abrahão A, Campos RE, Soares CJ. Finite element analysis of weakened roots restored with composite resin and posts. Dent Mater J. 2009 Nov;28(6):671-8.

32. da Silva NR, Raposo LH, Versluis A, Fernandes-Neto AJ, Soares CJ. The effect of post, core, crown type, and ferrule presence on the biomechanical behavior of endodontically treated bovine anterior teeth. JProsthet Dent. 2010 Nov:104(5):306-17. doi:10.1016/S0022-3913(10)60146-1.

33. Silva GR, Santos-Filho PC, Simamoto-Júnior PC, Martins LR, Mota AS, Soares CJ.Effect of post type and restorative techniques on the strain and fracture resistance of flared incisor roots. Braz Dent J. 2011;22(3):230-7.

34. Santos AF, Meira JB, Tanaka CB, Xavier TA, Ballester RY, Lima RG, etal. Can fiber posts increase root stresses and reduce fracture? JDent Res. 2010 Jun;89(6):587-91. doi: 10.1177/0022034510363382. Epub 2010 Mar 26.

35. Kinney,JH, Marshall, SJ,Marshall, GW. The mechanical properties of human dentin: a critical review and re-evaluation of the dental literature. Crit Rev Oral Biol Med. 2003;14(1):13-29.
36. Stewardson DA, Shortall AC,Marquis PM, Lumley PJ. The flexural properties of endodontic post materials. Dent Mater.2010 Aug;26(8):730-6. do: 10.1016/j. dental.2010.03.017.Epub 2010 Apr 21.

37. Daraio C, Nesterenko VF, Herbold EB, Jin S. Strongly nonlinear waves in a chain of Teflon beads. Phys RevEStat Nonlin Soft Matter Phys. 2005 Jul;,72(1Pt 2):016603. Epub 2005 Jul 6.

38. Fitton JS, Davies EH, Howlett JA, Pearson GJ. The physical properties of a polyacetal denture resin. Clin Mater. 1994;17(3):125-9.

39. Araújo EM, Melo TJA, Oliveira AD, Araúijo HL, Araújo KD, Barbosa R. Preparação de argilas organofilicas e desenvolvimento de nanocompósitos com matrizes poliméricas de polietileno enylon6. Parte 1: comportamento mecânico. Polímer Ciênc Tecnol. 2006;16(1):38-45.

40. Dantas RDLF.Estudo morfológico da blenda polimérica poli (metacrilato de metila)/poli (tereftalato de etileno) reciclado (PMMA/PET) [Master's thesis]. Natal (RN): Universidade Federal do Rio Grande do Norte;2011.

Profa. Dra. Andréa Candido dos Reis

(Corresponding address)

Departament of Dental Materials and Prosthesis, School of Dentistry of Ribeirão Preto, University of São Paulo - FORP-USP, Av. do Café, s/n 14040-904, Ribeirão Preto - SP, Brazil.

Telephone: +55-16-3602-4044.

E-mail: andreare73@yahoo.com.br

Date submitted: 2018 Aug 03 Accept submission: 2018 0ct 16 